\title{
To An Inconvertible Friend
}

The Russians are sullen.

The Russians are sad.

With rubles a-plenty,

No goods to be had.

No one wants rubles,

Abroad or at home.

Not Moscow, not Kiev,

Not London or Rome.

The root of the problem

Is incontrovertible.

Soviet rubles

Are nowhere convertible.

Help! There's no foreign

Exchange in the bank.

To whom can they turn?

There's no one but Frank.

For thirty-five years

That remarkable scholar

Has valued the ruble

In terms of the dollar.

You doubt his persistence?

All doubt will go 'way

If you check with the boys

At the CIA.

So he turned on his powerful

Tools of analysis.

How to surmount

The ruble's paralysis?
He pondered, he theorized,

Racked all his brains.

And this is the lesson

He boldly proclaimed.

"To market! To market!"

His essay adduced

(With a proper citation to

Mother Goose).

"The convertible ruble

Is simply about

How the Market is in

And how Planning is out."

Someday the Russians

Will warmly thank Frank

For the loans they receive

From the Fund and the Bank.

But we, his companions,

Suspect that his heart

Is not in the lesson

He seeks to impart.

The Youth of the 'thirties

Still dwells in the Man.

Though his Head's in the Market,

His Heart's in the Plan.

And so, in this party

We gladly take part

To honor our friend,

Both the Mind and the Heart.

--Joe Berliner ${ }^{1}$

1. Joe Berliner is Professor Emeritus of Economics at Brandeis University and poet laureate at the Harvard University Russian Research Center. 